\title{
A case of complete ipsilateral blindness and contralaetral monoparesis following dermafiller injection in the face
}

\author{
Habib O*, Salmi LA, Wani SA and AlSheef M \\ Division of Plastic \& Reconstructive Surgery, King Fahad Medical City, Riyadh, Saudi Arabia
}

\begin{abstract}
Filler injections are a common office procedures in the hands of a cosmetic surgeon. Cases of blindness, mostly irreversible, from aesthetic filler injections have been reported from Asia, Europe, and North America. Autologous fat appears to be the most frequent filler causing blindness. With the invent of newer generation filler substances with no specific antidote, their usage raises questions on the safety profile even in experienced hands.
\end{abstract}

We report a case of total ipsilateral blindness and contralateral hemiparesis following dermal injection of hylaluronic acid into the glabellar and nasal regions of face

\section{Introduction}

Blindness after injection of filler substances has been reported in many studies [1-4]. There have been reports of Cerebral infarction in some cases [5]. These disastrous effects have been attributed to iatrogenic, inadvertent injection of the substance in the arterial system of the region with consequent thrombosis to the endarteries. This happens when the vessel in punctured, the substance is injected into the lumen and moves retrograde all the way to endarteries like ophthalmic and even cerebral and upon withdrawal of the plunger, the pulsatile forward blood flow lodges it into the system causing acute occlusion $[6,7]$.

\section{Case report}

A 22 years old Unmarried Saudi female reported to us with a history of Complete right sided blindness, left monoparesis and skin necrosis following the injection of Hyaluronic acid in the face. The blindness and the monoparesis developed within few hours of the injection in the glabellar region whereas the skin necrosis gradually evolved over a period of days following the injection in the same and other areas of face. The patient reported 5 days after the injection to our multispecialty care hospital and was under the care of Stroke Unit with multispecialty involvements including thrombosis team, interventional radiology to either dissolve or dislodge the embolus. However, except for her monoparesis and skin lesions, progression of vision loss could not be haulted. Over a period of 3 weeks of inhospital stay, the patient showed complete recovery of her monoparesis, resolution of her skin lesions but with no improvement in vision of her right eye which continued to be 0/0with no light perception [8].

\section{Discussion}

Blindness following dermafiller injection is a rare but serious complication.

Lazzeri et al [3] in 2012, reported 32 cases of blindness following injection of fillers in the face, in which 15 cases developed complete blindness (FAT), remaining 17 were transitory (Non-FAT group). Again in 2012 Park et al [4], reported a series of 12 patients of Central retinal artery occlusion from Cosmetic filler, 2 cases in addition developed cerebral infarction(FAT). None recovered vision. Ozturk et al [5] in North America reported 61 cases of facial vascular occlusion by fillers other than Fat.12 had immediate blindness.

Based on the world-wide literature, it has been suggested to bear in mind the following golden rules to avoid/minimize the chances of inadvertent intravascular injection of the filler agent and subsequent serious effects [1]. Firstly, aspiration each time before injection which is the most important maneuver. Secondly as regards to the injected material, taking more care in cases of fat injections versus not-fat substances (fat as a filler has highest risk) and the use of vasoconstrictor with each procedure in appropriate doses. The other important domain is the nature of the needles used, it is advisable to use blunt and smaller guage needles to avoid vessel penetration. The volume injected has not to be more than 0.5 ccper pass with use of gentle force at each injection.

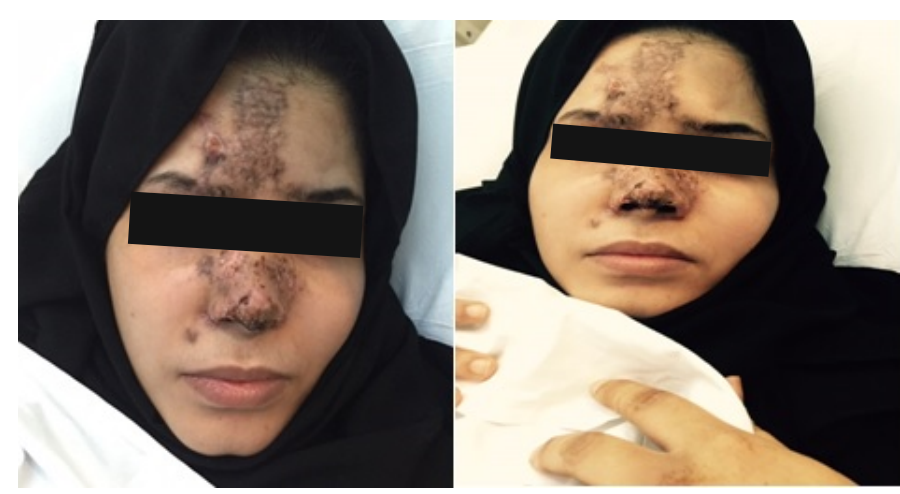

Figure 1. Complete right sided blindness with healing skin lesions (at 3 weeks).

Correspondence to: Ovais Habib, Plastic Surgeon, King Fahad Medical City Riyadh, kingdom Of Saudi Arabia, Tel: +966 11288 9999; E-mail: ovhabib@ kfmc.med.sa

Key words: hyaluronic acid, endarteries, monoparesis

Received: October 28, 2017; Accepted: November 14, 2017; Published: November 18, 2017 


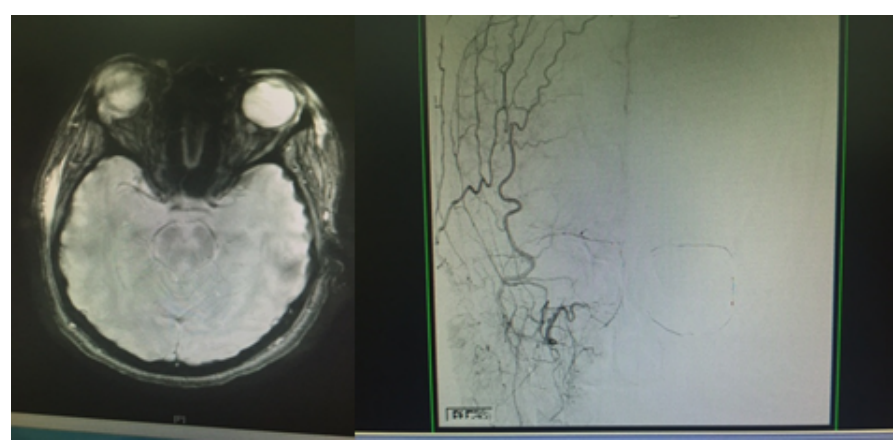

Figure 2. Infarction of the right optic nerve Absence of right retinal vascular blush (MRI) (Right carotid angiogram).

In the end it is advisable to have a specific antidote (if available) to the substance in the office to neutralize /minimize the effects of intraarterial injection [9-15].

\section{Consent}

Appropriate consents were taken from the patient to publish the content

\section{Conflicting results}

There were no conflicts of interest.

\section{References}

1. Carruthers JDA, Fagien S, Rohrich RJ, Weinkle S, Carruthers A (2014) Blindness Caused by Cosmetic Filler Injection: A Review of Cause and Therapy Plast Reconstr Surg 134: 1197-1201. [Crossref]
2. Sung MS, Kim HG, Woo KI, Kim YD (2010) Ocular ischemia and ischemic oculomotor nerve palsy after vascular embolization of injectable calcium hydroxylapatite filler. Ophthal Plast Reconstr Surg 26: 289-291. [Crossref]

3. Lazzeri D, Agostini T, Figus M, Nardi M, Pantalone M, et al. (2010) Blindness following cosmetic injections of the face. Plast Reconstr Surg 129: 994-1012. [Crossref]

4. Park SW, Woo SJ, Park KH, Huh JW, Jung C, et al. (2012) Iatrogenic retinal artery occlusion caused by cosmetic facial filler injections. Am J Ophthalmol 154: 653-662. [Crossref]

5. Ozturk CN, Li Y, Tunk R, Parker L, Piliang MP, et al. (2013) Complications following injection of soft-tissue fillers. Aesthet Surg J 33: 862-877. [Crossref]

6. Roberts SA, Arthurs BP (2012) Severe visual loss and orbital infarction following periorbital aesthetic poly-(L)-lactic acid (PLLA) injection. Ophthalmic Plast Reconstr Surg 28: e68-e70. [Crossref]

7. Coleman SR (2002) Avoidance of arterial occlusion from injection of soft tissue fillers Aesthet Surg J 22: 555-557. [Crossref]

8. Hayreh SS, Podhajsky PA, Zimmerman B (1997) Nonarteritic anterior ischemic optic neuropathy: time of onset of visual loss. Am J Ophthalmol 124: 641-647. [Crossref]

9. Jones D, Tezel A, Borrell M (2010) In vitro resistance to degradation of hyaluronic acid dermal fillers by ovine testicular hyaluronidase. Dermatol Surg 36:804-809.

10. DeLorenzi C (2013) Complications of injectable fillers, part I. Aesthet Surg J 33: 561575. [Crossref]

11. Fagien S (2013) Presentation. Allergan ALFA executive consultants meeting; New York, NY.

12. Raspaldo H (2013) Presentation in real time video. Allergan Executive Consultant Group Meeting, New York, NY.

13. Hirsch RJ, Brody HJ, Carruthers JD (2007) Hyaluronidase in the office: a necessity for every dermasurgeon that injects hyaluronic acid. J Cosmet Laser Ther 9: 182-185. [Crossref]

14. ISTA Pharmaceuticals (2003) Hyaluronidase (Vitrase)--ISTA: hyaluronidase--ISTA pharmaceuticals. Drugs R D 4: 194-197. [Crossref]

15. Therapeutic suggestions from Plastic and Reconstructive Surgery reviewer no. 2, May 2014.

Copyright: (C2017 Habib O. This is an open-access article distributed under the terms of the Creative Commons Attribution License, which permits unrestricted use, distribution, and reproduction in any medium, provided the original author and source are credited. 